\title{
Utilization of Agroresidual Waste in Effective Blending in Portland Cement
}

\author{
A. K. Parande, ${ }^{1}$ Karthick Stalin, ${ }^{2}$ Ravi Kumar Thangarajan, ${ }^{2}$ and M. S. Karthikeyan ${ }^{1}$ \\ ${ }^{1}$ Centre for Education, CECRI, Karaikudi 630006, India \\ ${ }^{2}$ Corrosion Protection Division, Central Electrochemical Research Institute (CECRI), Karaikudi 630006, India
}

Correspondence should be addressed to A. K. Parande, corrparande@yahoo.co.in

Received 5 January 2011; Accepted 1 March 2011

Academic Editor: H. A. Mang

Copyright (C) 2011 A. K. Parande et al. This is an open access article distributed under the Creative Commons Attribution License, which permits unrestricted use, distribution, and reproduction in any medium, provided the original work is properly cited.

\begin{abstract}
Indigenous resources for natural and artificial mineral admixtures with high pozzolanic reactivity have been employed in many countries around the world. Extensive studies have been conducted for this purpose. With the use of agricultural waste residue, apart from improving properties of concrete, main benefits come from saving natural resources and energy, as well as protecting the environment by using these mineral admixtures (agroagricultural waste). The effective level of blending Portland cement (PC) in mortar or concrete with such mineral admixtures depends on many factors, such as the type of admixture and the cement replacement level. In the present paper two types of agroagricultural waste residue, namely, rice husk ash, bagasse ash and byproduct from thermal waste and fly ash were used. The above mentioned admixtures were thermally treated at a temperature of $650^{\circ} \mathrm{C}$. Characterizations of mineral admixtures were carried out by FTIR and XRD, and Microstructural properties were evaluated in concrete and mortar with partially replacement levels varying from $5 \%$ to $30 \%$. Various tests such as water absorption, bulk volume of the specimen, dry weight of the specimen saturated mass, and coefficient of water absorption were concluded. The results showed that as the percentage of replacement level increases in the entire three admixtures studied, water absorption also increased.
\end{abstract}

\section{Introduction}

Indian cement industry comprises 120 large cement plants besides some 300 miniplants, with a total installed capacity of about 118 million tones and a production of 98 million tones (1999).

The major industrial waste products are fly ash from thermal power plants, rice husk from rice mills, bagasse ash from sugar industries, blast furnace slag from metal extraction plants, silica fume, and microsilica from ferrosilicon alloy metal industries. Apart from these materials, metakaolin (China clay) is also used after mechanical treating in concrete as partial cement replacement material. Some of the agrowaste products such as vegetable fibers saw dust ash and so forth, are only at an experimental stage. Sewage sludges are also used in concrete as partial replacement cement material after necessary treatment.

1.1. Agroresidues. Agricultural residues are normally composed of organic constituents such as cellulose, lignin, fibers and small amounts of crude protein and fat. In addition, they contain a range of minerals, which include silica, alumina and iron oxides. The agrowastes cannot be used directly to replace cement and it requires thermal treatment, which is often called pyroprocessing. When an agroresidue is considered for utilizing in concrete to replace certain percentage of cement, two important factors are to be considered: its ash content and chemical constituents. The silica content of the ash is another important factor because it will react with the lime $\mathrm{Ca}(\mathrm{OH})_{2}$ to produce calcium silicate hydrate $(\mathrm{CSH})$ which is responsible for development of strength and other microstructural properties of concrete. Table 1 gives the physical properties of rice husk ash.

1.2. Rice Husk Ash as a Pozzolana. Rice husk ash (RHA) has been tried as pozzolanic material with cement mortar and concrete since RHA contains more than $80 \%$ silicon dioxide $\left(\mathrm{SiO}_{2}\right)$ and little quantity of alumina $\left(\mathrm{Al}_{2} \mathrm{O}_{3}\right)$, and also the RHA is alkaline in nature. Till 1972, the RHA was obtained 
TABLe 1: Physical and chemical properties of the cement and RHA.

\begin{tabular}{|c|c|c|}
\hline Properties & Cement & RHA \\
\hline \multicolumn{3}{|l|}{ Physical properties } \\
\hline Moisture content & - & $3.68 \%$ \\
\hline Specific gravity & 3.12 & 2.08 \\
\hline Fineness & $2975 \mathrm{~cm}^{2} / \mathrm{g}$ & $12.5 \%$ (Retained $45 \mathrm{~mm}$ sieving) \\
\hline \multicolumn{3}{|l|}{ Chemical composition } \\
\hline Silica $\left(\mathrm{SiO}_{2}\right)$ & $20.44 \%$ & $93.15 \%$ \\
\hline Alumina $\left(\mathrm{Al}_{2} \mathrm{O}_{3}\right)$ & $5.50 \%$ & $0.21 \%$ \\
\hline Iron oxide $\left(\mathrm{Fa}_{2} \mathrm{O}_{3}\right)$ & - & $0.21 \%$ \\
\hline Calcium oxide $(\mathrm{CaO})$ & $64.86 \%$ & $0.41 \%$ \\
\hline Potash $\left(\mathrm{K}_{2} \mathrm{O}\right)$ & - & $22.31 \%$ \\
\hline Magnesia (MgO) & $1.59 \%$ & $0.45 \%$ \\
\hline Loss on ignition & $1.51 \%$ & $2.36 \%$ \\
\hline $\mathrm{pH}$ & 12.06 & 9.83 \\
\hline $3 \mathrm{CaO} \cdot \mathrm{SiO}_{2}$ & $66.48 \%$ & - \\
\hline $2 \mathrm{CaO} \cdot \mathrm{SiO}_{2}$ & $10.12 \%$ & - \\
\hline $3 \mathrm{CaO} \cdot \mathrm{Al}_{2} \mathrm{O}_{3}$ & $8.06 \%$ & - \\
\hline $3 \mathrm{CaO} \cdot \mathrm{Al}_{2} \mathrm{O}_{3} \cdot \mathrm{Fe}_{2} \mathrm{O}_{3}$ & $9.43 \%$ & - \\
\hline Free lime & $1.65 \%$ & - \\
\hline
\end{tabular}

by an uncontrolled method by burning and was utilized for brick making with the composition of lime and cement [1]. In 1972, Mehta [2-4] in the United States published the first several papers dealing with rice husk utilization. Thermal treatment to the RHA activates the $\mathrm{SiO}_{2}$ content for the pozzolanic activity with Ordinary Portland cement (OPC) in presence of water. By considering all these aspects, the RHA can be used as a pozzolanic material with partial replacement of OPC in concrete making.

1.3. Fly Ash. Coal ash production and utilization in the world with emphasis on its use in concrete was studied by Anwar et al. [5]. According to Bhanumathidas and Mehta [6] the fly ash production in China is approximately 100 million tons per year in 1997.

Chindaprasirt et al. [7] studied the effects of adding carbonate to ashes during melting. High-temperature phase transformations were studied by X-ray diffraction (XRD) analysis and the glass phase was studied by Fourier transform infrared spectroscopy (FT-IR) analysis. It was shown that addition of carbonates results in a glass phase with a higher pozzolanic reactivity than the parent coal glass.

\section{Materials and Methodology}

The scope and objective of the present investigation is as follows:

(1) microstructural properties in concrete and mortar such as water absorption, bulk volume of the specimen, dry weight of the specimen, saturated mass, coefficient of water absorption, capillary suction, and modified sorptivity using fly ash, rice husk ash, and bagasse ash in different replacement levels from 5\% to $35 \%$ in ordinary Portland cement;
(2) to evaluate the rice husk at $650^{\circ} \mathrm{C}$ in concrete at different replacement levels;

(3) to evaluate the bagasse ash studies in concrete by thermally treated at different replacement levels;

(4) to study the different replacement levels of fly ash from 5 to $35 \%$ in concrete.

2.1. Materials Used. The following materials were used for the present study.

Ordinary Portland Cement: 43 grade OPC-IS 8112.

Graded Fine Aggregates: Local clean river sand (fineness modulus of medium sand equal to 2.6) confirming to grading zone III of IS : 383-1970 was used as fine aggregates.

Graded Coarse Aggregates: Locally available wellgraded aggregates of normally size greater than $4.75 \mathrm{~mm}$ and modulus of 2.72 was used as coarse aggregates.

The composition of OPC used in this study is reported in Table 2.

\subsection{Experimental Works}

2.2.1. Preparation of Materials. Experiments were considered with both concrete and mortar specimens. The materials used, for specimens were ordinary Portland cement (OPC) of 43 grade "Dalmia" brand, conforming to IS:8112, river sand was used by screening through $1: 18 \mathrm{~mm}$ sieve. The river sand for the specimen preparation had the fineness modulus 2.85. The rice husk ash used was collected from local rice mills in Puthuvayal. Fly ash was collected from 
TABLE 2: Composition of OPC used in this study.

\begin{tabular}{lc}
\hline Constituents & OPC \\
\hline $\mathrm{SiO}_{2}$ & 21.04 \\
$\mathrm{Fe}_{2} \mathrm{O}_{3}$ & 3.35 \\
$\mathrm{Al}_{2} \mathrm{O}_{3}$ & 9.93 \\
$\mathrm{CaO}$ & 60.68 \\
$\mathrm{MgO}$ & 1.30 \\
$\mathrm{Na}_{2} \mathrm{O}$ & 0.20 \\
$\mathrm{~K}_{2} \mathrm{O}$ & 0.90 \\
Loss on ignition & 2.60 \\
\hline
\end{tabular}

The mix design used for casting was $1: 1.5: 3$.

Water-to-cement ratio was $(\mathrm{w} / \mathrm{c})=0.53$.

Neyveli Thermal power station. Bagasse ash was collected from private sugar mills at Aranthangi.

With the use of fly ash, rice husk, and bagasse ash concrete, specimens were prepared using as received only.

But in the case of mortar specimens, two types of mineral admixtures were used that is, rice husk and bagasse ash (agrowaste product). Rice husk and Bagasse ash were subjected to being thermally treated.

RHA ash were used was thermally treated and mineral admixtures were burnt at $650^{\circ} \mathrm{C}$ for two hours in electric furnace and pulverized to $50 \mu \mathrm{m}$ and down-sized.

Control specimens and cast for both concrete and mortar specimens using the above mix ratios. The above mineral admixtures were used as supplementary cementing material to replace OPC partially. The replacement levels for fly ash was $5 \%, 10 \%, 15 \%, 20 \%, 30 \%$ and $35 \%$ by weight of cement, similarly for rice husk and bagasse ash the replacement levels were from $5 \%$ to $30 \%$ only. For all mix proportions, the quantity of sand and water was kept constant. The mortar specimens were caste in duplicate.

Standard-size moulds were used for casting cubes and cylinder. In case of treated and untreated mixtures, first the ash was blended with OPC thoroughly, subsequently mixed well with dry sand and finally water was added and mixed to obtain even mixture. Each mould was given an oil coating for easy demoulding. After 24 hours from casting, the specimens were demoulded. The specimens were cured in a separate curing tank with tap water for 28 days. After 28 days of curing the specimens were retrieved from the tank and allowed to dry in open air before testing.

2.2.2. Techniques Adopted. Characterization of mineral admixture by Fourier transform infrared spectroscopy (FTIR) and X-Ray diffraction (XRD).

\section{(1) Microstructural Properties Tests.}

(a) Standard test method for water absorption, specific gravity, bulk density and permeable voids in hardened concrete (ASTM-C642-97).

(b) Coefficient of water absorption.

\section{Results and Discussion}

3.1. Microstructural Properties of Fly Ash Concrete. Table 3 shows the microstructural properties of fly ash concrete. From the table, it is observed that the percentage of water absorption is found to be slightly higher than the control concrete. It is also observed that the percentage of volume of permeable voids and effective porosity is found to be higher than the control concrete. As the replacement levels increases from $5 \%$ to $35 \%$, the permeable voids and porosity are also found to be in increasing trend.

Table 3 shows the microstructural properties of fly ash mortar replaced at different level ranging from 5\% to $35 \%$. From the observation made, it is inferred from the table that all the parameters studied such as percentage of permeable voids and effective porosity are found to be higher than the controlled concrete, when compared to rice husk at different replacement levels.

Although the fly ash mortar showed higher volume of permeability and poor pore structure, this may be due to less pozzolanic reaction in mortar and also the mortar specimens, capillary pores play a vital role in increasing the porosity and also the chemical reaction tends to absorb more water.

\subsection{Microstructural Properties of Rice Husk Concrete/Mortar} (RHA). Tables 4 and 5 show the microstructural properties of the various parameter studies such as water absorption, volume of permeable voids, effective porosity, and so forth, from the rice husk concrete.

From Table 4, it is observed that the percentage of water absorption after immersion for controlled concrete is found to be $4.31 \%$ and for the rice husk ash replaced concrete, the percentage of water absorption is found to be increased from $4.52 \%$ to $6.027 \%$. This variation in percentage is observed due to the supplementary cementitious material (SCM) with partial replacement up to $30 \%$.

From Table 5, it is inferred that there is an increase in trend of water absorption. Beyond 30\%, the water absorption is found to decrease. The bulk density, specific gravity after drying, immersion, and boiling of microstructural properties is found in the range 2.07 to $3.0086,2.1992$ to 3.1679 , and 2.2101 to 3.1777 , respectively, for rice husk replaced concrete. The effective porosity for controlled concrete is found to be 10.06 whereas rice husk replaced concrete is in the range of 11.892 to 18.18 . As the replacement level increases, the effective porosity was found to be decreased. This may be due to the incomplete formation of CSH gel formation.

3.3. Microstructural Properties of Bagasse Ash Concretel Mortar. Tables 6 and 7 show the microstructural properties of bagasse ash treated at $650^{\circ} \mathrm{C}$. From the table, it is observed that the percentage of volume of permeable voids that for controlled concrete is found to be $11.21 \%$ and for different replacement level for bagasse ash replaced concrete varied from 13.72 to 18.79 . When compared to the controlled concrete, bagasse ash replaced concrete are performing higher percentage of volume of permeable voids and higher 


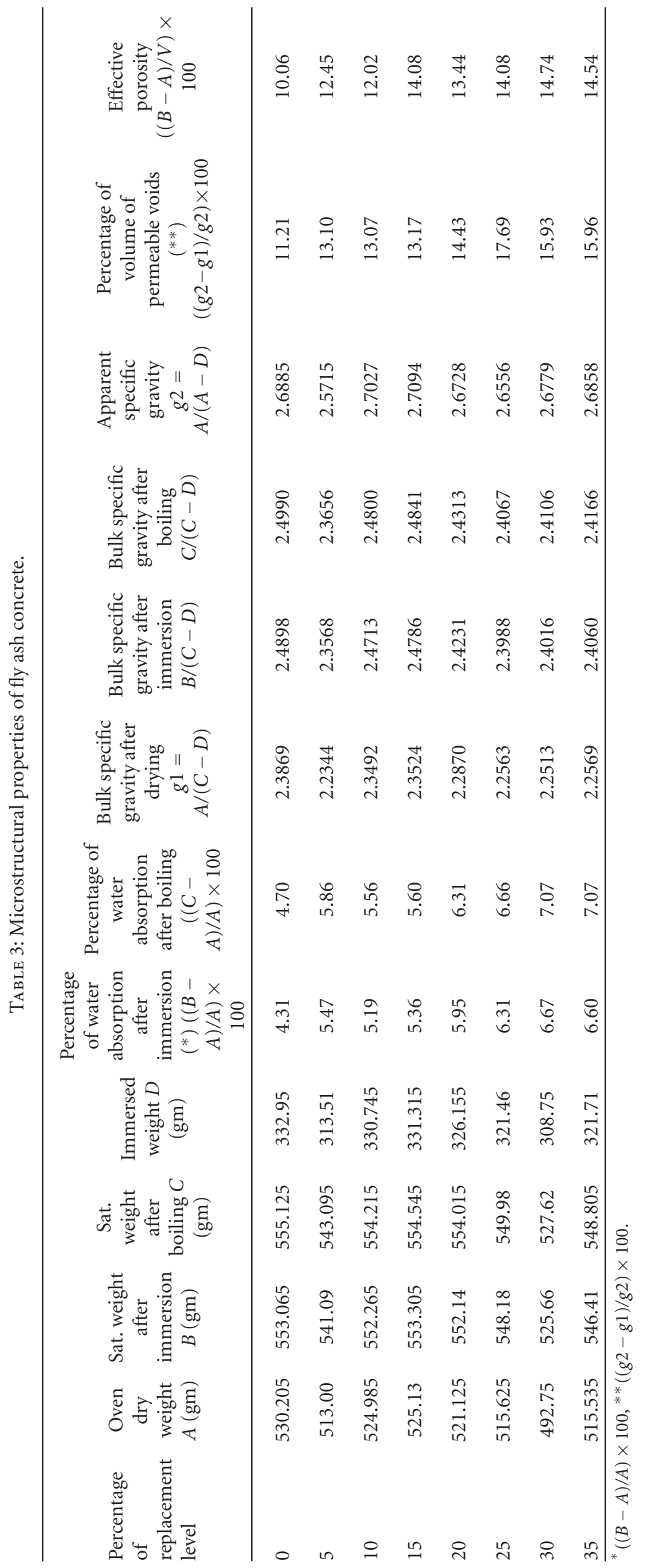




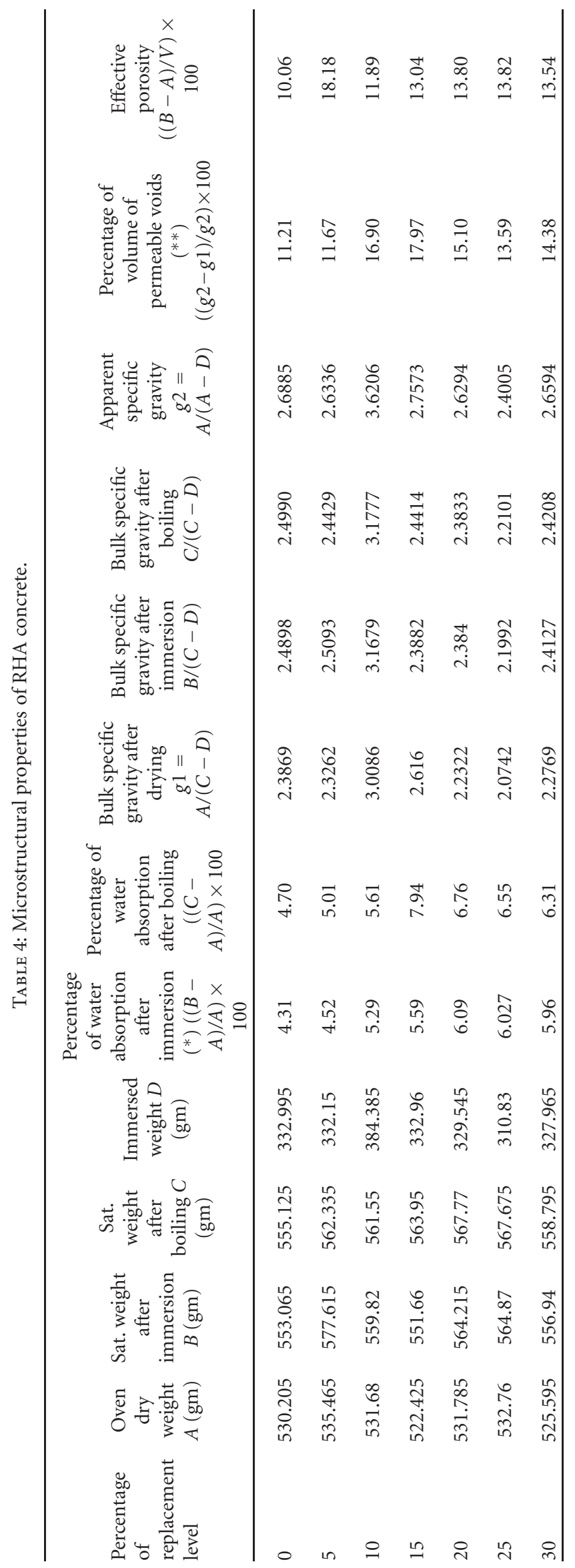




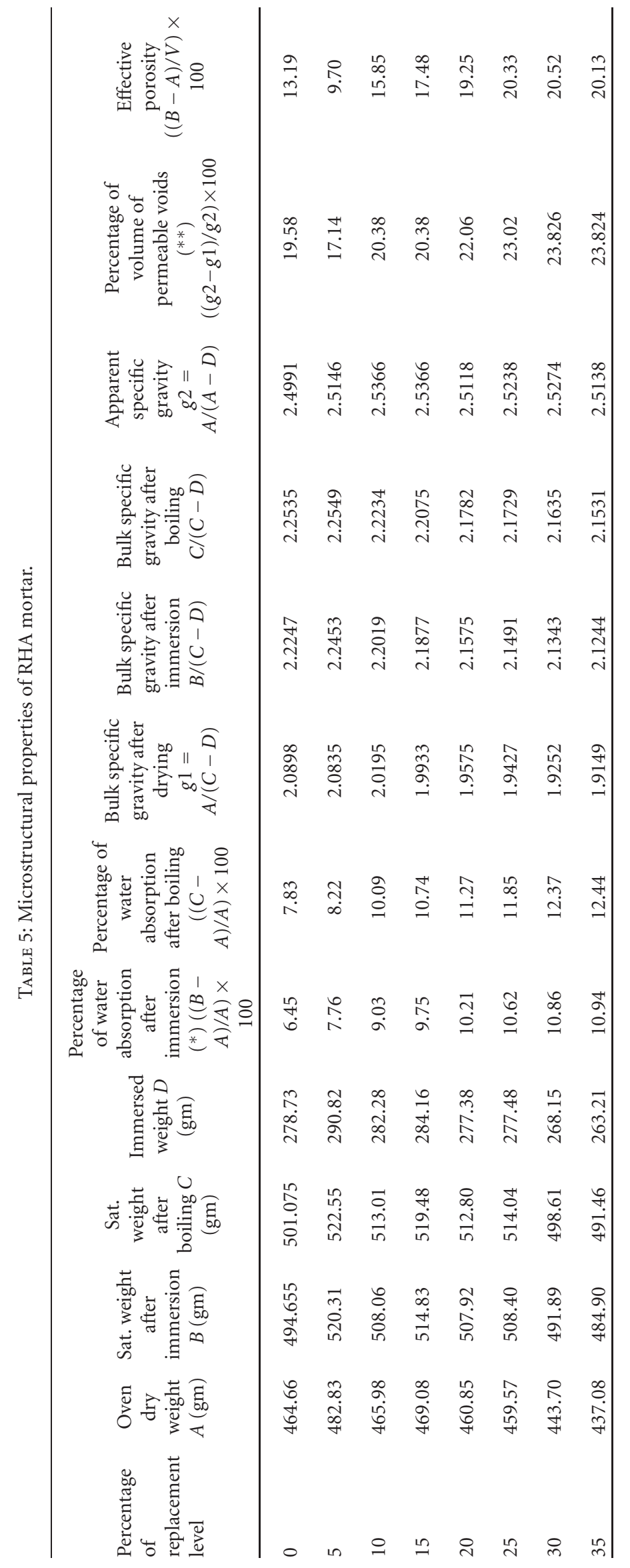


porosity. This may be due to the delayed Pozzolanic reaction of the ash mortar. It is inferred from the table that all the microstructural properties such as water absorption, percentage of permeable voids, effective porosity are found to be higher than the controlled mortar. When compared to rice husk at different replacement varying from 5 to $35 \%$ at the same level, the bagasse ash mortar showed higher percentage of permeable voids and higher effective porosity. This may be due to less pozzolanic reaction in the formation of calcium silicate hydrate $(\mathrm{CSH})$ gel.

3.4. Coefficient of Water Absorption for Fly Ash Concrete. Table 8 shows the coefficient of water absorption for fly ash concrete. From the table, it is observed that the coefficient of water absorption was found to be 3.5771 and for different replacement level, it varies because of the varying suction area. Also there exists a variation in the volume of water absorbed.

3.5. Coefficient of Water Absorption for Rice Husk Ash Concrete/Mortar. Table 9 shows the coefficient of water absorption for rice husk ash concrete. From the table, it is observed that the coefficient of water absorption was found to be 3.5771, and for different replacement level for rice husk ash replaced concrete varied from 0.10320 to 1.4548 .

Table 10 shows the coefficient of water absorption for rice husk ash mortar. From the table, it is observed that the coefficient of water absorption was found to be 6.4796 and for different replacement level for rice husk ash replaced mortar varied from 5.457 to 10.378 .

3.6. Reaction Mechanism of RHA with Cement. When RHA is added to Portland cement, it reacts faster than fly ash in the hydration process, which helps to improve the early age strength of concrete, and also forms calcium silicate hydrate (CSH) gel around the cement particles which is highly dense and less porous. The formation of $\mathrm{CSH}$ gel in concrete alters the microstructure of the concrete with discontinuous pores. The pore refinement or densification reduces the permeability of concrete and improves the resistance against chloride diffusion into concrete $[8,9]$. Yu et al. [10] carried out some experiments with RHA in partial replacement with cement concrete and proposed the following sequence of reaction in strength development.

Reaction of tricalcium silicate (C3S) and dicalcium silicate $(\mathrm{C} 2 \mathrm{~S})$ :

Portland cement $+\mathrm{H}_{2} \mathrm{O} \longrightarrow \mathrm{CSH}+\mathrm{Ca}(\mathrm{OH})_{2}$,

Portland cement $+\mathrm{RHA}+\mathrm{H}_{2} \mathrm{O} \longrightarrow \mathrm{CSH}+$ unreacted silica.

In 1990, Boateng and Skeete [11] explained the formation of $\mathrm{CSH}$ gel with two kinds of CSH gels as CSH I and CSH II as shown below:

$$
\mathrm{Ca}(\mathrm{OH})_{2}+\mathrm{SiO}_{2} \longrightarrow \mathrm{CSHI}+\mathrm{CSHII},
$$

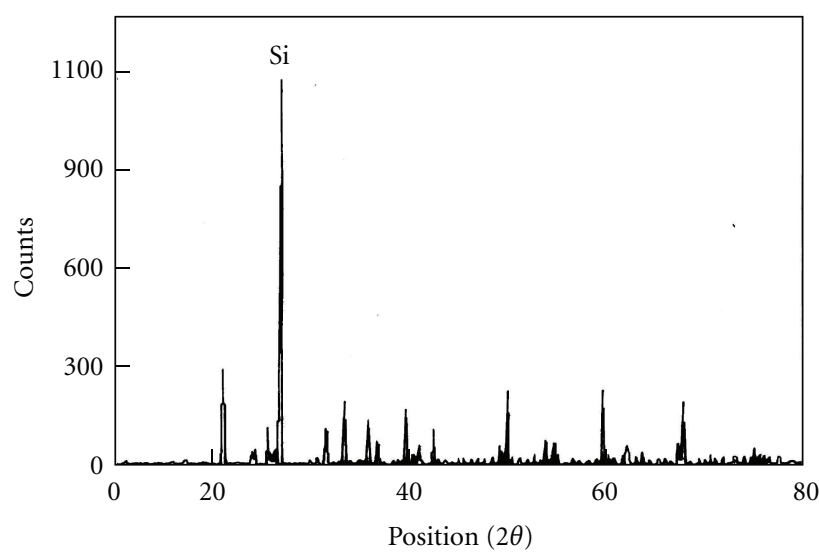

(a)

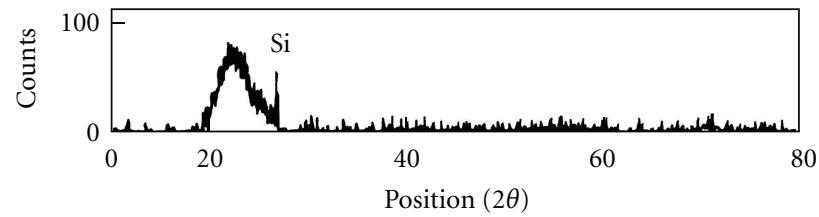

(b)

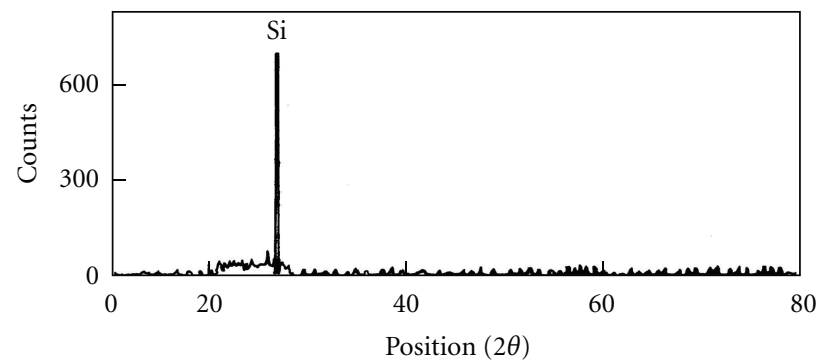

(c)

Figure 1: (a) XRD pattern of fly ash, (b) XRD pattern of RHA, and (c) XRD pattern of bagasse ash.

where

$$
\begin{aligned}
& \mathrm{CSHI}=\mathrm{CaO}_{0.8-1.5} \mathrm{SiO}_{2}\left(\mathrm{H}_{2} \mathrm{O}\right)_{1.0-2.5}, \\
& \text { CSHII }=\mathrm{CaO}_{1.5-2.0} \mathrm{SiO}_{2} \cdot 2\left(\mathrm{H}_{2} \mathrm{O}\right) .
\end{aligned}
$$

3.7. X-Ray Diffraction. Figures 1(a), 1(b), and 1(c) show the XRD patterns obtained for three mineral admixtures studied: (a) fly ash, (b) rice husk ash, and (c) bagasse ash respectively. It can be seen from the XRD profile of metakaolin that the intensity of the reflections are significantly high, indicating highly crystalline nature of the sample. The orderly crystalline characteristic of the sample could be beneficial to be an efficient mineral admixture. This fact is well reflected from the experimental results. In the case of the bagasse ash and fly ash (Figure 1(a)) also the XRD peaks are of high intensity. The peak signatures for calcite and silicates could be seen, and this fact is supported from the experimental data.

3.8. Fourier Transform Infrared Spectroscopy. FTIR spectra of the absorbent materials, namely, fly ash, rice husk ash, and bagasse ash recorded between wave number $4000-450 \mathrm{~cm}^{-1}$ 


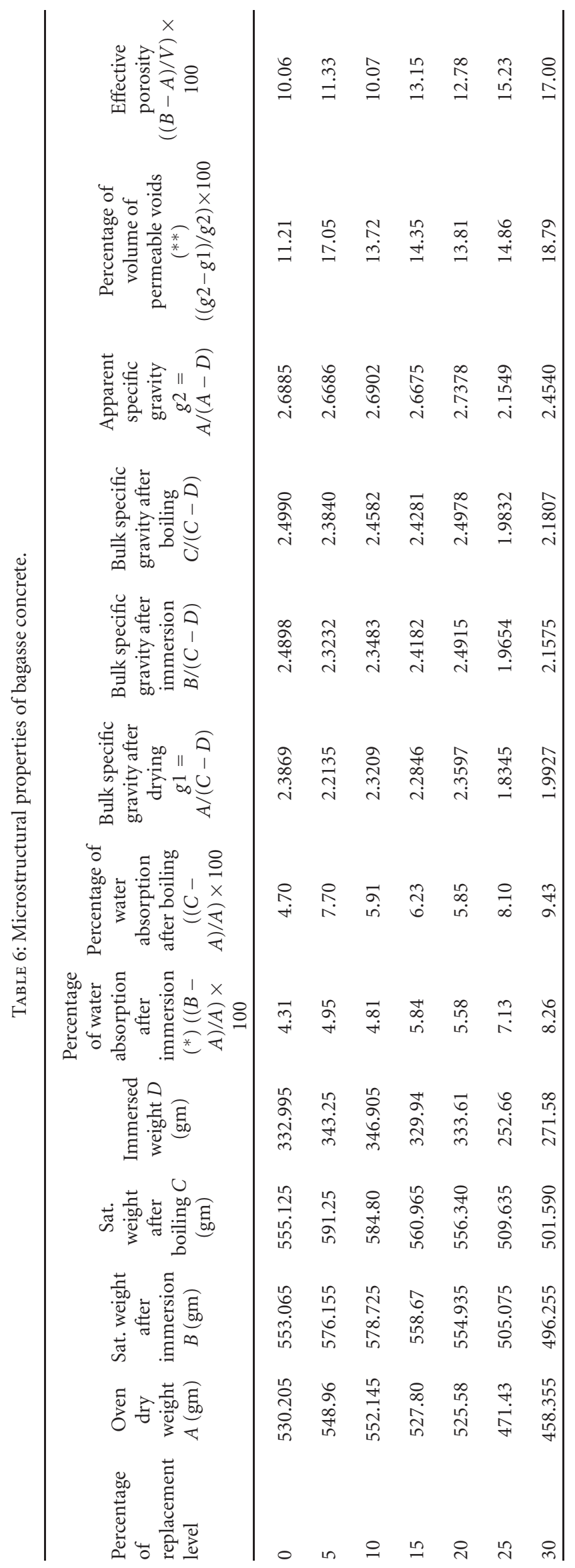




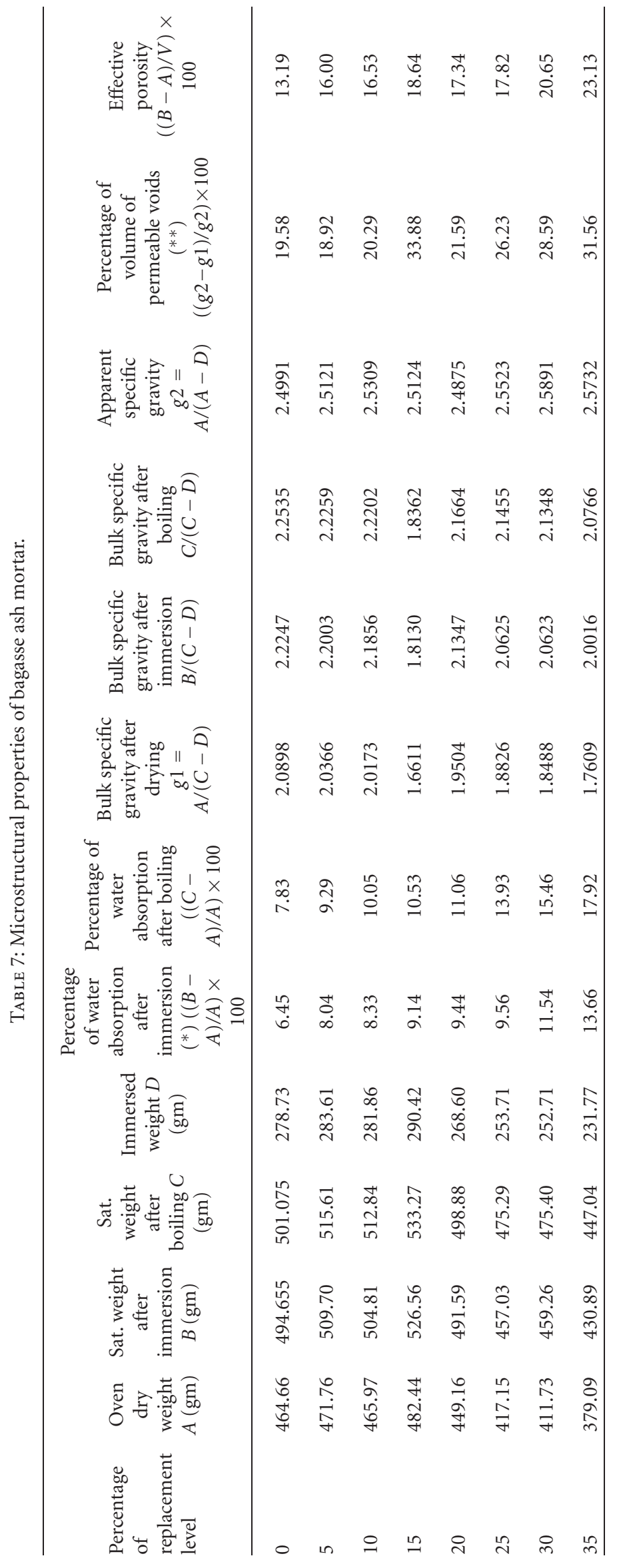


TABLE 8: Coefficient of water absorption for fly ash concrete.

\begin{tabular}{|c|c|c|c|c|c|c|}
\hline $\begin{array}{l}\text { Percentage of } \\
\text { replacement level }\end{array}$ & $\begin{array}{l}\text { Area of suction } \\
\qquad\left(\mathrm{cm}^{2}\right)\end{array}$ & $\begin{array}{l}\text { Initial mass } \\
\qquad(\mathrm{gm})\end{array}$ & $\begin{array}{l}\text { Final mass } \\
\qquad(\mathrm{gm})\end{array}$ & $\begin{array}{l}\text { Mass of } \\
\text { water } \\
\text { absorbed } \\
(\mathrm{gm})\end{array}$ & $\begin{array}{l}\text { Volume of } \\
\text { water } \\
\text { absorbed } \\
\mathrm{Q}(\mathrm{mL})\end{array}$ & $\begin{array}{l}\text { Coefficient of water absorption } \\
K a=(Q / A)^{2}(1 / t) 10^{-10}\left(\mathrm{~m}^{2} / \mathrm{sec}\right)\end{array}$ \\
\hline 0 & 55.4951 & 537.30 & 543.58 & 6.28 & 6.28 & 3.5571 \\
\hline 5 & 56.5029 & 547.79 & 555.73 & 7.94 & 7.94 & 5.4852 \\
\hline 10 & 54.3657 & 524.97 & 526.38 & 1.41 & 1.41 & 0.18684 \\
\hline 15 & 54.6011 & 531.82 & 535.20 & 3.38 & 3.38 & 1.0644 \\
\hline 20 & 55.4159 & 534.08 & 536.55 & 2.47 & 2.47 & 0.55185 \\
\hline 25 & 54.6011 & 527.56 & 530.45 & 2.89 & 2.89 & 0.77819 \\
\hline 30 & 55.7859 & 537.75 & 542.67 & 4.92 & 4.92 & 2.1606 \\
\hline 35 & 54.5487 & 518.92 & 526.11 & 7.19 & 7.19 & 4.8259 \\
\hline
\end{tabular}

TABLE 9: Coefficient of water absorption for RHA concrete.

\begin{tabular}{|c|c|c|c|c|c|c|}
\hline $\begin{array}{l}\text { Percentage of } \\
\text { replacement level }\end{array}$ & $\begin{array}{l}\text { Area of suction } \\
\qquad\left(\mathrm{cm}^{2}\right)\end{array}$ & $\begin{array}{l}\text { Initial mass } \\
\qquad(\mathrm{gm})\end{array}$ & $\begin{array}{l}\text { Final mass } \\
\qquad(\mathrm{gm})\end{array}$ & $\begin{array}{l}\text { Mass of } \\
\text { water } \\
\text { absorbed } \\
(\mathrm{gm})\end{array}$ & $\begin{array}{c}\text { Volume of } \\
\text { water } \\
\text { absorbed } \\
\mathrm{Q}(\mathrm{mL})\end{array}$ & $\begin{array}{l}\text { Coefficient of water absorption } \\
K a=(Q / A)^{2}(1 / t) 10^{-10}\left(\mathrm{~m}^{2} / \mathrm{sec}\right)\end{array}$ \\
\hline 0 & 55.4951 & 537.30 & 543.58 & 6.28 & 6.28 & 3.5571 \\
\hline 5 & 55.5479 & 552.93 & 555.67 & 2.74 & 2.74 & 0.67587 \\
\hline 10 & 54.52261 & 524.96 & 526.01 & 1.05 & 1.05 & 0.10320 \\
\hline 15 & 55.1261 & 554.69 & 556.24 & 1.55 & 1.55 & 0.21960 \\
\hline 20 & 55.0998 & 563.88 & 567.52 & 3.64 & 3.64 & 1.2122 \\
\hline 25 & 55.5479 & 557.27 & 561.29 & 4.02 & 4.02 & 1.4548 \\
\hline 30 & 55.6272 & 562.14 & 565.95 & 3.81 & 3.81 & 1.3030 \\
\hline
\end{tabular}

are presented in Figures 2(a), 2(b), and 2(c) respectively. The spectrum shows the absorption bands at around $3413 \mathrm{~cm}^{-1}$, which could be ascribed to $\mathrm{OH}$ stretching vibration in the structure. The band at around $1629 \mathrm{~cm}^{-1}$ was an $\mathrm{H}-\mathrm{OH}$ vibration whereas the broad band at $3413 \mathrm{~cm}^{-1}$ was due to vibration $(\mathrm{OH})$ in structural water [12]. Chloride does not absorb in the range $450-4000 \mathrm{~cm}^{-1}$. The band at $794 \mathrm{~cm}^{-1}$ represented the presence of symmetric and asymmetric vibrations of $\mathrm{Al}-\mathrm{OH}$ band in $\mathrm{Al}(\mathrm{OH}) 6$ octahedral structure of fly ash cement matrices.

FTIR spectra of rice husk and bagasse are depicted in Figures 2(b) and 2(c), respectively. The peak at $1103 \mathrm{~cm}^{-1}$ which corresponds to the Si-O-Si asymmetric vibration and due to the greater ionic character of the Si-O group [13]. This spectrum also exhibits bands at 804 and $470 \mathrm{~cm}^{-1}$. Si-O bending band vibrations, respectively. This data indicates that the silica phase found in RHA was completely amorphous due to the absence of bands near $622 \mathrm{~cm}^{-1}$ which is identical to tridymite (crystalline phase) that shows the presence of the cristobalite phase [14].

Spectra of bagasse in fig depicted the absorption at $3432 \mathrm{~cm}^{-1}$ is attributed to the stretching of $-\mathrm{OH}$ groups. The C-H stretching vibration gives signals at $2928 \mathrm{~cm}^{-1}$. The band at $1623 \mathrm{~cm}^{-1}$ is due to the bending mode of absorbed water.

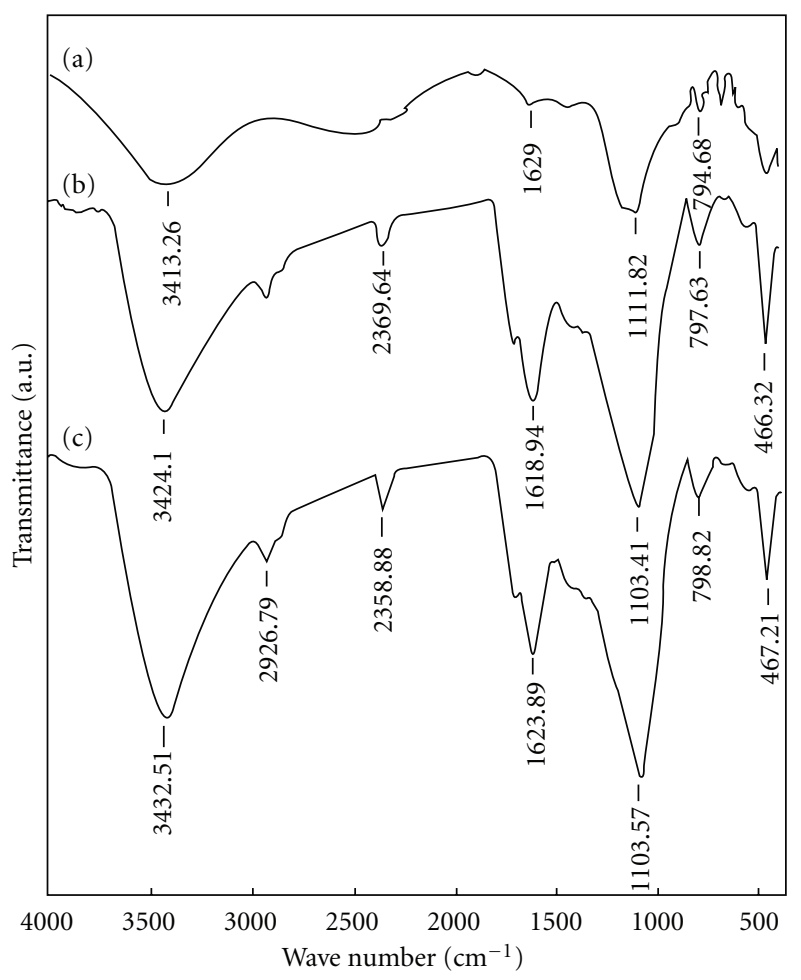

FIGURE 2: (a) FTIR spectra of fly ash, (b) FTIR spectra of RHA, and (c) FTIR spectra of bagasse ash. 
TABLE 10: Coefficient of water absorption for RHA mortar.

\begin{tabular}{|c|c|c|c|c|c|c|}
\hline $\begin{array}{l}\text { Percentage of } \\
\text { replacement level }\end{array}$ & $\begin{array}{l}\text { Area of suction } \\
\qquad\left(\mathrm{cm}^{2}\right)\end{array}$ & $\begin{array}{l}\text { Initial mass } \\
\quad(\mathrm{gm})\end{array}$ & $\begin{array}{l}\text { Final mass } \\
\quad(\mathrm{gm})\end{array}$ & $\begin{array}{l}\text { Mass of } \\
\text { water } \\
\text { absorbed } \\
(\mathrm{gm})\end{array}$ & $\begin{array}{c}\text { Volume of } \\
\text { water } \\
\text { absorbed } \\
\mathrm{Q}(\mathrm{mL})\end{array}$ & $\begin{array}{c}\text { Coefficient of water absorption } \\
K a=(\mathrm{Q} / \mathrm{A})^{2}(1 / t)\left(\mathrm{m}^{2} / \mathrm{sec}\right)\end{array}$ \\
\hline 0 & 55.6536 & 473.54 & 482.04 & 8.5 & 8.5 & 6.4796 \\
\hline 5 & 55.1787 & 469.85 & 479.73 & 9.88 & 9.88 & 8.9051 \\
\hline 10 & 55.7594 & 466.16 & 475.68 & 9.52 & 9.52 & 8.0972 \\
\hline 15 & 55.9421 & 465.26 & 475.88 & 10.62 & 10.62 & 10.378 \\
\hline 20 & 56.5029 & 447.32 & 457.87 & 10.55 & 10.55 & 9.6841 \\
\hline 25 & 55.4423 & 447.14 & 458.91 & 11.77 & 11.77 & 12.518 \\
\hline 30 & 56.2900 & 437.31 & 445.20 & 7.89 & 7.89 & 5.457 \\
\hline 35 & 56.0244 & 439.54 & 448.32 & 8.78 & 8.78 & 6.8223 \\
\hline
\end{tabular}

\section{Conclusion}

Based on the results of investigation in this work, the following conclusions were drawn.

The admixture studies for the three systems are drawn as follows: A higher replacement level in RHA content leads to lower strength characteristics of concrete and increases water absorption. This is due to the fact that quantity of RHA present in excess quantity will not combine with the lime liberated during the process of hydration and hence leading to excess silica leached out of the concrete and causing a deficiency in strength.

Owing to the fineness and microstructure of the RHA, it absorbs and retains water when mixed in concrete. Therefore, shrinkage cracks may develop on the exposed surfaces.

(1) As the \% of replacement of rice husk ash in concrete and mortar increased the $\%$ of water absorption was also increased gradually from $5 \%$ to $30 \%$.

(2) The effective porosity for control concrete system was found to be good when compared to others at different replacement levels in fly ash, RHA and bagasses ash.

(3) Microstructural properties in bagasse ash mortar (percentage of water absorption, percentage of permeable voids, effective porosity) found to be higher than control mortar from 5\%-35\% of replacement.

(4) Coefficient of water absorption studies, showed that when compared to control system, the fly ash concrete performance in replacement level $10 \%$ to $30 \%$ was superior from other two systems studied (RHA concrete and RHA mortar). But on the other hand coefficient of water absorption for RHA concrete decreased from $5 \%$ to $30 \%$ of replacement.

Although thermally treated RHA is superior to fly ash and bagasse ash, in water absorption studies, the disadvantage in RHA content leads to lower strength characteristics as explained above. This is also due to quantity of RHA present will not combine with lime liberated during the hydration process. With these properties, fly ash has an upper hand in the hydration process and forms the secondary hydration gel, and the fly ash can be used as supplementary cementitious material in various applications.

\section{References}

[1] D. J. Cook, "Rice husk ash," in Concrete Technology and Design, Cement Replacement Materials, R. N. Swamy, Ed., vol. 3, pp. 171-196, Surrey University Press, London, UK, 1986.

[2] P. K. Mehta, "Properties of blended cements made from rice husk ash," Journal of the American Concrete Institute, vol. 74, no. 9, pp. 440-442, 1977.

[3] P. K. Mehta, "The chemistry and technology of cements made from rice husk ash," in Proceedings of UNIDO/ESCAP/RCTT, Workshop on Rice-Husk Ash Cement, pp. 113-122, Peshawar, Pakistan, 1979.

[4] P. K. Mehta and D. Pirtz, "Use of rice hull ash to reduce temperature in high-strength mass concrete," Journal of American Concrete Institute, vol. 75, no. 2, pp. 60-63, 1978.

[5] M. Anwar, T. Miyagawa, and M. Gaweesh, "Using rice husk ash as a cement replacement material in concrete," Waste Management Series, vol. 1, pp. 671-684, 2000.

[6] N. Bhanumathidas and P. K. Mehta, "Concrete mixtures with ternary blended cements containing fly ash and rice husk ash," in Proceedings of the 7th CANMET/ACI International Conference on Durability of Concrete (CANMET/ACI '01), pp. 379-391, Chennai, India, June 2001.

[7] P. Chindaprasirt, S. Rukzon, and V. Sirivivatnanon, "Resistance to chloride penetration of blended Portland cement mortar containing palm oil fuel ash, rice husk ash and fly ash," Construction and Building Materials, vol. 22, no. 5, pp. 932938, 2008.

[8] K. Ganesan and K. Rajagopal, "Thangavel rice husk ash blended cement: assessment of optimal level of replacement for strength and permeability properties of concrete," Construction and Building Materials, vol. 22, no. 8, pp. 1675-1683, 2008.

[9] J. James and M. Subba Rao, "Reaction product of lime and silica from rice husk ash," Cement and Concrete Research, vol. 16, no. 1, pp. 67-73, 1986.

[10] Q. Yu, K. Sawayama, S. Sugita, M. Shoya, and Y. Isojima, "Reaction between rice husk ash and $\mathrm{Ca}(\mathrm{OH})_{2}$ solution and the nature of its product," Cement and Concrete Research, vol. 29 , no. 1 , pp. 37-43, 1999. 
[11] A. A. Boateng and D. A. Skeete, "Incineration of rice hull for use as a cementitious material: the guyana experience," Cement and Concrete Research, vol. 20, no. 5, pp. 795-802, 1990.

[12] F. Peng, J. L. Ren, F. Xu, J. Bian, P. Peng, and R. C. Sun, "Comparative study of hemicelluloses obtained by graded ethanol precipitation from sugarcane bagasse," Journal of Agricultural and Food Chemistry, vol. 57, no. 14, pp. 63056317, 2009.

[13] G. Socrates, Infrared Characteristics Group Frequencies: Tables and Charts, Wiley, New York, NY, USA, 1994.

[14] H. A. Willis, J. H. der Mas, and R. G. J. Miller, Laboratory Methods in Vibrational Spectroscopy, Wiley, New York, NY, USA, 1987. 

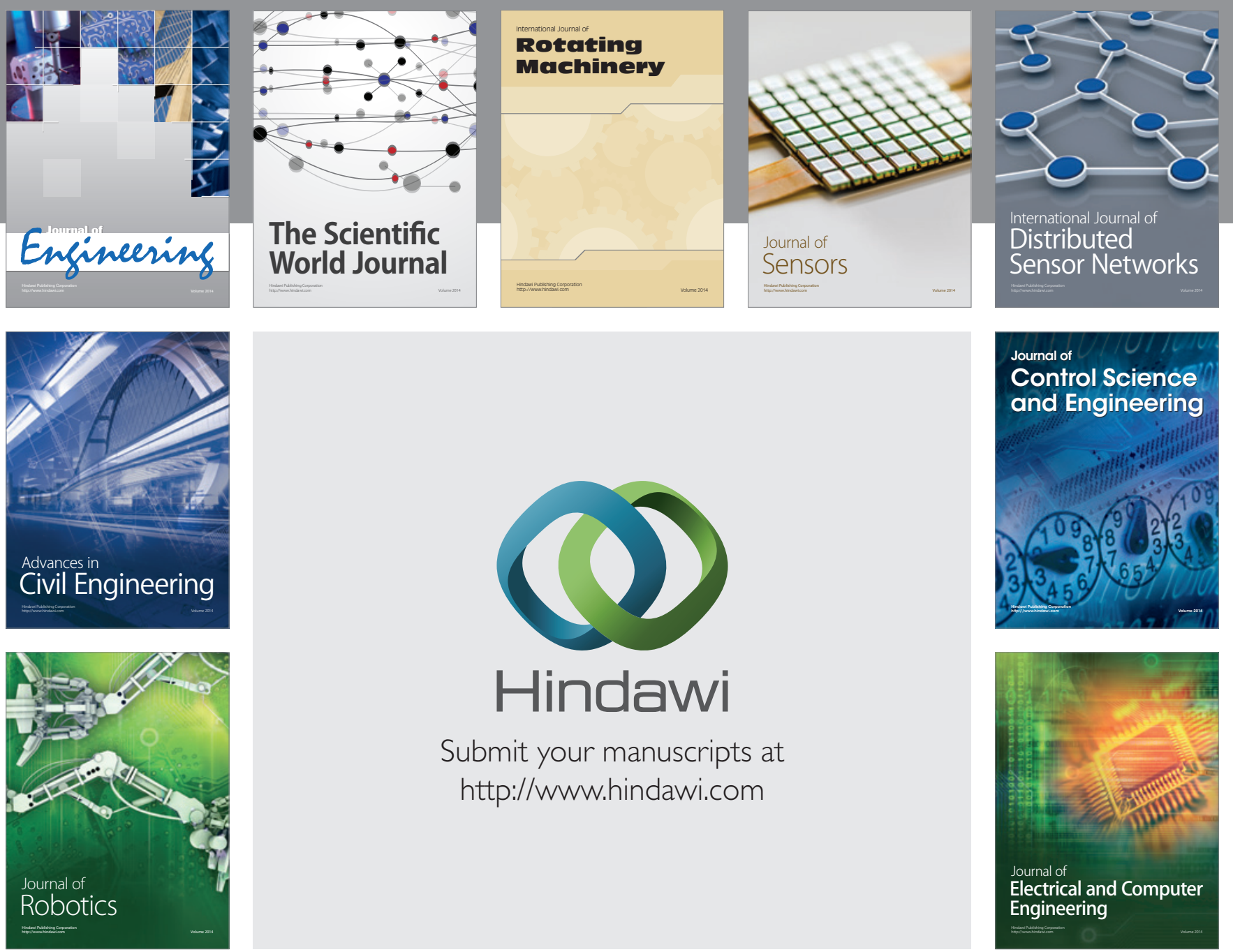

Submit your manuscripts at

http://www.hindawi.com
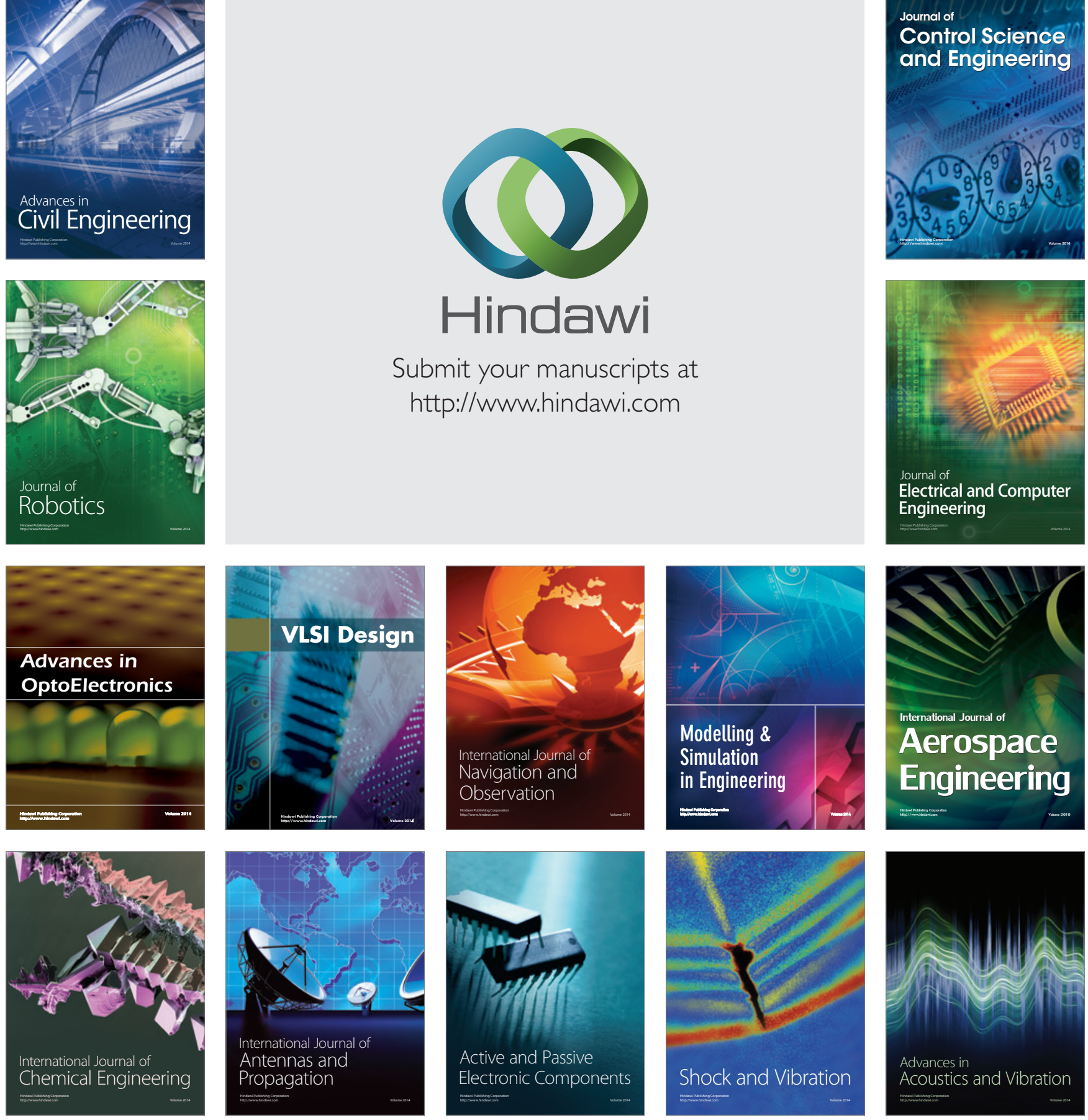